\title{
Fasciola hepatica Infection in Echinococcosis Suspected Cases
}

\section{Ekinokokkozis Şüpheli Olgularda Fasciola hepatica Enfeksiyonu}

\author{
Nermin Şakru, Metin Korkmaz², Mustafa Demirci ${ }^{3}$, Aydınten Kuman², Ülgen Zeki Ok ${ }^{4}$ \\ 1Department of Medical Microbiology, Faculty of Medicine, Trakya University, Edirne, Turkey \\ 2Department of Parasitology, Faculty of Medicine, Ege University, İzmir, Turkey \\ ${ }^{3}$ Department of Medical Microbiology, Faculty of Medicine, Süleyman Demirel University, Isparta, Turkey \\ ${ }^{4}$ Department of Parasitology, Faculty of Medicine, Celal Bayar University, Manisa, Turkey
}

\section{ABSTRACT}

Objective: Fasciola hepatica, a liver fluke of sheep and cattle, may accidentally infect humans. The main signs and symptoms of the fasciolosis are eosinophilia, abdominal pain and hepatomegaly and may also be attributed to Cystic Echinococcosis (CE) caused by Echinococcus granulosus, which is a prevalent infection in Turkey.

Methods: Sera samples of 226 CE suspected cases were tested for anti-F. hepatica antibodies by an excretory secretory ELISA (ES-ELISA) and for anti-E. granulosus antibodies by ELISA and indirect hemagglutination (IHA) tests. Cases which were seropositive for fasciolosis were further evaluated radiologically and examined for $F$. hepatica eggs.

Results: Five (2.2\%) and 96 (42.4\%) of the 226 CE suspected cases were found seropositive for fasciolosis and CE, respectively. Although the radiological findings strongly suggested that there was fasciolosis in three cases, F. hepatica eggs were detected in two patients only. Conclusion: These data suggest that human fasciolosis is not as rare as previously reported in Turkey. F. hepatica infection should be suspected especially in the presence of eosinophilia, abdominal pain and liver lesions. (Turkiye Parazitol Derg 2011; 35: 77-80)

Key Words: Echinococcosis, fasciolosis, Turkey

Received: 20.01.2011

Accepted: 27.02.2011

\section{ÖZET}

Amaç: Koyun ve sığırların karaciğer kelebeği olan Fasciola hepatica; insanları tesadüfen enfekte edebilir. Fasciolosisin eozinofili, karın ağrısı ve hepatomegali gibi başlıca bulgu ve belirtileri Türkiye'de de yaygın bir enfeksiyon olan, Echinococcus granulosus'un neden olduğu Kistik Ekinokokkozise de (KE) bağlı olabilir.

Yöntemler: KE olduğu şüphelenilen 226 olgunun serum örnekleri; $F$. hepatica'ya karşı oluşan antikorlar yönünden salgısal ELISA (ES-ELISA) testiyle, E. granulosus antikorları için ELISA ve indirekt hemaglütinasyon (IHA) testleriyle çalışılmıştır. Seropozitif fasciolosis olguları ayrıca radyolojik olarak değerlendirilmiş ve $F$. hepatica yumurtaları açısından incelenmiş̧ir.

Bulgular: 226 KE şüpheli olgudan beşi (\%2.2) fasciolosis ve 96'sı (\%42.4) KE için seropozitif olarak bulunmuştur. Radyolojik bulgular; üç olgunun fasciolosis olduğunu doğrulamasına rağmen ancak iki hastada $F$. hepatica yumurtaları bulunmuştur.

Sonuç: Bu veriler; insan fasciolosisinin Türkiye'de bildirildiği gibi nadir olmadığını düşündürmektedir. Özellikle eozinofili, karın ağrısı ve karaciğer lezyonları varlığında F. hepatica enfeksiyonundan şüphelenilmesi yerinde olacaktır. (Turkiye Parazitol Derg 2011; 35: 77-80)

Anahtar Sözcükler: Ekinokokkozis, fasciolosis, Türkiye

Geliş Tarihi: 20.01.2011

Kabul Tarihi: 27.02.2011

This study is presented in $11^{\text {th }}$ European Congress of Clinical Microbiology and Infectious Diseases (1 - 4 April 2001, istanbul, Turkey) Address for Correspondence / Yazışma Adresi: Dr. Nermin Şakru, Department of Medical Microbiology, Faculty of Medicine, Trakya University, Edirne, Turkey Phone: +90 2842357641 E-mail: nsakru@yahoo.com

doi:10.5152/tpd.2011.20 


\section{INTRODUCTION}

Fasciola hepatica, the sheep liver fluke, is a common parasite of herbivores in Turkey, as in many regions of the world. Human fasciolosis has been reported in many countries including Turkey (1-7). Echinococcus granulosus has a world-wide geographic distribution and is a public health problem in many parts of the Mediterranean region, China, Africa, Australia and South America. Between 2001 and 2005, various hospitals and Health Ministry documents have recorded 14,789 cases of human Cystic Echinococcosis (CE) in Turkey $(8,9)$.

In the last decade, important advances in the diagnosis and treatment of fasciolosis have been achieved. Definitive diagnosis of the infection may be established by the observation of the parasite ova in the feces, but most cases are diagnosed by serological methods. Serological tests allow diagnosis in the acute stage; even before the parasite eggs can be identified in the stool. ESELISA is reported to be a rapid and sensitive test, which detects antibodies against the excretory-secretory antigens produced by the adult $F$. hepatica $(6,10-12)$.

The clinical spectrum of fasciolosis is wide; therefore, a high index of suspicion is required to establish a correct diagnosis. Liver lesions, urticaria and eosinophilia are the main clinical signs and symptoms of the infection, which are also common in some other helminthic infections. Since CE is a widespread infection in Turkey, these signs and symptoms may initially be attributed to CE. Diagnosis of CE is mainly based on imaging techniques; however serological tests may provide specific confirmation of CE both in clinical and community screening studies (13-15).

In the present study, we aimed to evaluate a group of clinically and/or radiologically suspected CE cases, referred to the Department of Parasitology, for the presence of fasciolosis.

\section{MATERIALS AND METHODS}

Sera samples of 226 cases, clinically and/or radiologically suspected of CE, were also evaluated for anti-F. hepatica antibodies. These cases had been referred to the Department of Parasitology, Medical Faculty of Ege University, for examination of anti-E.granulosus antibodies because of epigastric and / or right upper quadrant pain and/or urticaria and/or eosinophilia and/or jaundice and / or hepatomegaly.

Serum samples were tested using ELISA (16) and indirect hemaglutination (IHA) (17) tests for echinococcosis; and by using ES-ELISA for fasciolosis (4). Cases found to be seropositive for fasciolosis were further evaluated by ultrasonography and/or computerized tomography (CT) scan and their stool samples were examined for F. hepatica eggs by formalin-ethyl acetate concentration method.

All patients found to be positive for fasciolosis were treated with a single, post-prandial, $10 \mathrm{mg} / \mathrm{kg}$ oral dose of triclabendazole, and re-examined one, three and six months after treatment by all the laboratory tests.

\section{RESULTS}

Of the 226 CE suspected cases, 150 patients were female and 76 were male, and their ages ranged between 2 and 75 years (mean $43.4 \pm 13.9$ years). From these cases; five (2.2\%) and 96 (42.4\%) were found seropositive for fasciolosis and CE, respectively. None of them were positive for both infections. Among five cases seropositive for fasciolosis, one patient could not be reached for further evaluation and another, who showed a weak seropositivity, could not be confirmed either parasitologically or radiologically. Three patients were diagnosed as fasciolosis. The clinical history of three confirmed fasciolosis cases are summarized below:

Case 1: A 22-year-old woman suffered from right upper quadrant pain and urticaria for 2 months. Ultrasonography and CT scan of the liver revealed several intrahepatic hypodense lesions (Figure 1). White blood cell (WBC) count was $10,800 / \mathrm{mm}^{3}$ with $50.6 \%$ eosinophils and liver enzymes were normal. Multiple parasitologic examinations of her stool samples were negative for $F$. hepatica eggs; and she was regarded to be in the acute stage of fasciolosis.

Case 2: A 47-year-old woman was admitted to hospital with chest pain, cough and weight loss complaints. WBC counts ranged from 9.000 to $14.500 / \mathrm{mm}^{3}$, with $13-48 \%$ eosinophils. Her red blood cell sedimentation rate was $40 \mathrm{~mm} / \mathrm{h}$ and alkaline phosphatase level was found to be mildly increased (198 U/I). The chest $\mathrm{x}$-ray and CT scan revealed nodular lesions in the median and superior lobes of the right lung. F. hepatica eggs were detected in her stool sample.

Case 3: A 47-year-old man who presented with a painful abdominal mass, had experienced intermittent abdominal pain and malaise for 5 years. The laboratory findings were normal except for eosinophilia (18\%). A CT scan of the abdomen revealed a tumor type mass, adjacent to the colon. He had undergone an operation with the prediagnosis of intestinal malignity. The microscopic examination of the biopsy revealed no cancer cells, but necrotic material and Charcot-Leyden crystals suggesting a parasitic infection. F. hepatica eggs were identified after a detailed examination of multiple sections of the resection material (Figure 2).

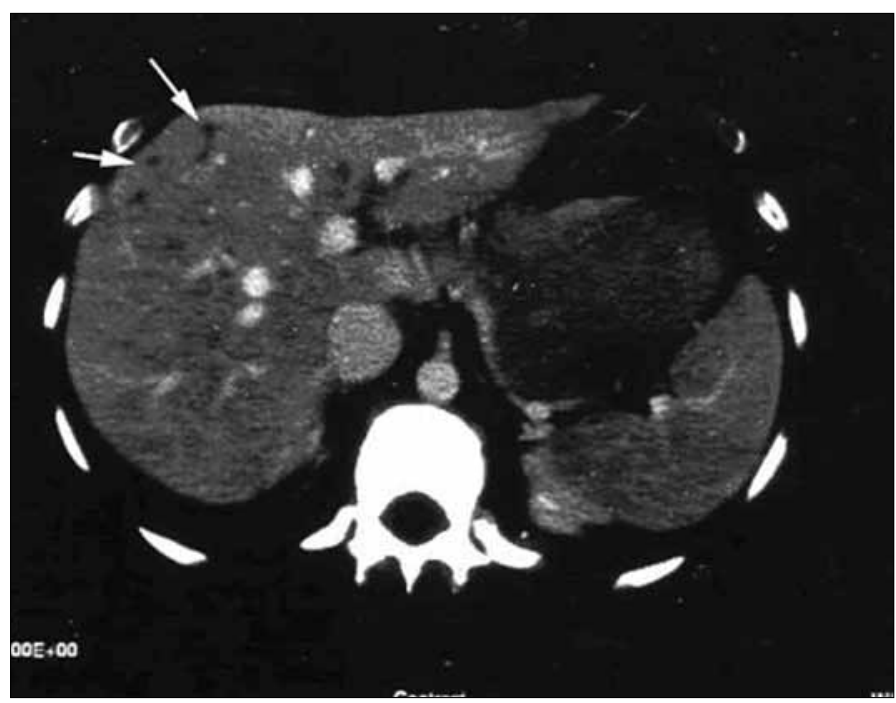

Figure 1. CT scan of the liver revealed several intrahepatic hypodense lesions (case 1) 


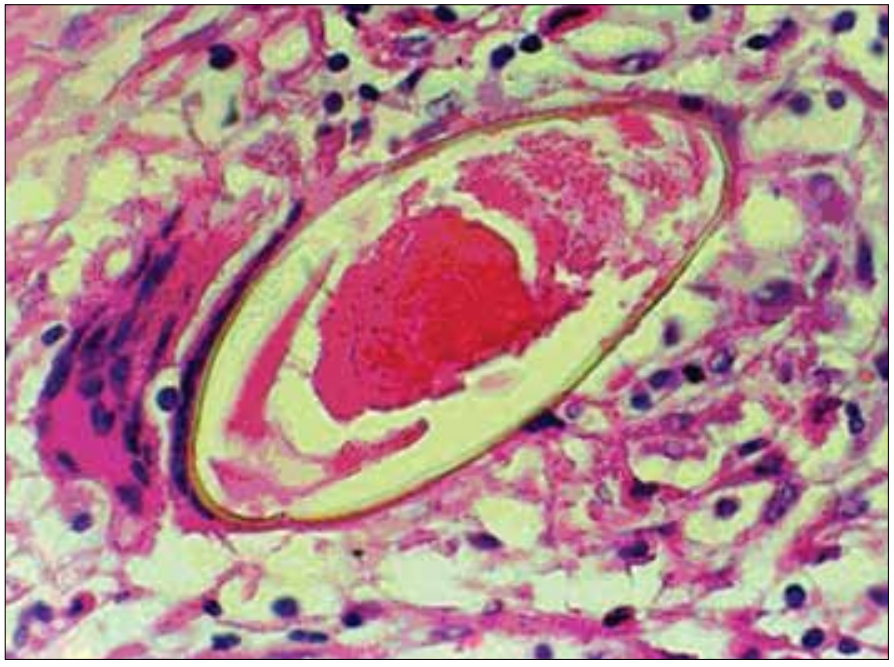

Figure 2. F. hepatica egg in the resection material of case 3 (original magnification $\times 1000$, H\&E stain)

\section{DISCUSSION}

Fasciolosis is caused by two species of the genus Fasciola: F. hepatica, and F. gigantica. Studies carried out in recent years have shown that this infection is a serious public health problem worldwide and the number of reports of human infection in 51 countries of all continents is increasing. At present, major health problems are known in Andean countries (Bolivia, Peru, Chile, Ecuador), the Caribbean area (Cuba), northern Africa (Egypt), western Europe (Portugal, France and Spain) and the Caspian area (Iran and neighbouring countries) $(2,18)$.

Signs and symptoms associated with CE such as fever, epigastric and right upper quadrant pain, urticaria, leukocytosis, eosinophilia, mild to moderate anemia, jaundice, enlarged tender liver, and respiratory symptoms, may also be associated with other helminthic infections, such as fasciolosis. F. hepatica infection may be misdiagnosed in patients showing these symptoms (1, 2, 19-21). Patients included in our study group showed one or more signs related with $C E$, which may also be found in fasciolosis.

Our first case presented a good argument for the advantage of serological tests and the lack of value of the stool examinations, in the diagnosis of early stage fasciolosis. This patient had the most common presentation of acute stage of fasciolosis: an acute or subacute illness with a combination of symptoms including abdominal pain, malaise, and marked eosinophilia.

The clinical spectrum of fasciolosis is variable, and patients may present with extrahepatic abnormalities, such as pulmonary infiltrates, pleuropericarditis, meningitis, or lymphadenopathy. Eosinophilia is the most frequent laboratory abnormality; hepatomegaly and urticaria are also common in fasciolosis. Some patients have symptoms related to other organ systems and the pathogenesis of these manifestations is obscure $(1,2)$. Interestingly, respiratory system symptoms, such as chest pain and cough, were dominant in the second patient. Diagnosis is difficult in such cases, but eosinophilia should raise the suspicion of fasciolosis.

F. hepatica occasionally bypasses the liver and migrates to other tissues, resulting in ectopic fasciolosis, with the parasite located in extrahepatic tissues $(1,2,22,23)$. It is reported that larvae of
F. hepatica usually do not reach maturity in ectopic foci $(1,2)$; however F. hepatica eggs were detected in the resection material of the third patient, who had an ectopic focus in a cystic mass next to the colon.

Identifying parasite eggs in stool samples was the main diagnostic method previously. However, this method lacks sensitivity, because eggs do not appear during the migrating stage. Even in the late stages, multiple stool examinations are often needed to demonstrate eggs, and in many cases eggs are never detected $(1,2)$. In all of our three cases, stool samples were examined for $F$. hepatica eggs by formaline-ether concentration procedure, but only one case was positive.

Our data suggested that fasciolosis is not rare in Turkey. All cases suspected of CE should also be examined for fasciolosis before more invasive approaches, especially if they have eosinophilia, abdominal pain and liver lesions.

\section{Conflict of Interest}

No conflict of interest was declared by the authors.

\section{REFERENCES}

1. Arjona R, Riancho JA, Aguado JM, Salesa R, Gonzalez Macias J. Fascioliasis in developed countries: A review of classic and aberrant forms of the diseases. Medicine 1995; 74: 13-23. [CrossRef]

2. Mas-Coma MS, Bargues MD, Esteban JG. Human fasciolosis in: Dalton JP eds. Fasciolosis. Wallingford: CABI publishing, 1999; 411-34.

3. Bengisun U, Özbaş S, Sarıoğlu U. Fascioliasis observed during laparoscopic cholecystectomy. Langenbeck's Arch Surg 1999; 384: 84-7. [CrossRef]

4. Demirci M, Korkmaz M, Kaya S, Kuman A. Fascioliasis in eosinophilic patients in the Isparta region of Turkey. Infection 2003; 31:15-8. [CrossRef]

5. Kayabali I, Gökçora iH, Yerdel MA, Örmeci N. Hepatic fascioliasis and biliary surgery. Int Surg 1992; 77: 154-7.

6. Ozturhan H, Emekdaş G, Sezgin O, Korkmaz M, Altıntaş E. Seroepidemiology of Fasciola hepatica in Mersin province and surrounding towns and the role of family history of the Fascioliasis in the transmission of the parasite. Turk J Gastroenterol 2009; 20: 198-203.

7. Bahçecioğlu IH, Yalniz M, Ataseven H, Kuzu N, Ilhan F, Erensoy A. Biliyer Fasciolosis: ERCP ile Tanı Konulan Üç Olgu Raporu. Turkiye Parazitol Derg 2008; 32: 375-8.

8. Eckert J, Schantz PM, Gasser RB, Torgerson PR, Bessonov AS, Movsessian SO, et al. Geographic distribution and prevalence. Eckert J, Gemmell MA, Meslin F.-X, Pawlowski ZS, Editors. WHO/ OIE manual on Echinococcosis in humans and animals: a public health problem of global concern. Paris: World organisation for animal health;2002.p.101-43.

9. Yazar S, Ozkan AT, Hökelek M, Polat E, Yilmaz H, Ozbilge H, ve ark. Türkiye'de 2001-2005 Yılları Arasında Kistik Ekinokokkozis Turkiye Parazitol Derg 2008; 32: 208-20.

10. Espino AM, Dumenigo BE, Fernandez R, Finlay CM. Immunodiagnosis of human fascioliasis by enzyme-linked immunosorbent assay using excretory-secretory products. Am J Trop Med Hyg 1987; 37: 605-8.

11. Santiago de Weil N, Hillyer GV, Pacheco E. Isolation of Fasciola hepatica genus-specific antigens. Int J Parasitol 1984; 14: 197-206. [CrossRef]

12. Sakru N, Korkmaz M, Kuman HA. Comparison of two different enzyme immunoassays in the diagnosis of Fasciola hepatica infections. Mikrobiyol Bul 2004; 38(1-2):129-35.

13. Pawlowski ZS. Critical points in the clinical management of cystic echinococcosis. Andersen FL, Chai J, Liu F, editors. Compendium 
on Cystic Echinococcosis - with Special Reference to Xinjiang Uygur Autonomous Region, The People's Republic of China. Provo, UT, Brigham Young University, 1993.119-31.

14. Markell EK, John DT, Krotoski WA. The Cestodes. Markell and Voge's Medical Parasitology, 8th edition, Pennsylvania: WB Saunders Company; 1999; 234-68

15. Pawlowski ZS, Eckert J, Vuitton DA, Ammann RW, Kern P, Craig PS, et al. Echinococcosis in humans: clinical aspects, diagnosis and treatment. Eckert J, Gemmell MA, Meslin F.-X, Pawlowski ZS, Editors. WHO/OIE manual on Echinococcosis in humans and animals: a public health problem of global concern. Paris: World organisation for animal health;2001; 20-72.

16. Wen $\mathrm{H}$, Craig PS. Immunglobulin $\mathrm{G}$ subclass response in human cystic and alveolar echinococcosis. Am J Trop Med Hyg 1994; 51: 741-8.

17. Varela-Diaz VM, Lopez-Lemes MH, Prezioso U, Coltorti EA, Yarzabal LA. Evaluation of four variants of the indirect hemagglutination test for human hydatidosis. Am J Trop Med Hyg 1975; 24: 304-11.
18. Mas-Coma S. Human fascioliasis. Cotruvo JA, Dufour A, Rees G, Bartram J, Carr R, Cliver DO, Craun GF, Fayer R,Gannon VPJ, editors. Waterborne Zoonoses: Identification, Causes and Control. World Health Organization (WHO), London, UK: IWA Publishing; 2004.p. 305-22

19. Tekin A, Kücükkartallar T, Kartal A, Kaynak A, Ozer S, Tavli S, et al. Clinical and surgical profile and follow up of patients with liver hydatid cyst from an endemic region. J Gastrointestin Liver Dis 2008; 17: 33-7.

20. Mıman O, Atambay M, Aydin NE, Daldal N. Kistik Ekinokokkozis Nedeniyle Opere Edilmiş 91 Olguda Klinik, Morfolojik ve Serolojik Irdelemeler. Turkiye Parazitol Derg 2010; 34: 179-83.

21. Moro P, Schantz PM. Echinococcosis: a review. Int J Infect Dis 2009; 13: 125-33. [CrossRef]

22. Yazici G, Dilek UT, Karabacak T, Ertunc D, Korkmaz M, Dilek S. Adnexal fascioliasis masquerading as ovarian cancer. Gynecol Oncol 2005; 99: 236-8. [CrossRef]

23. Yi-Zhu $X$, Zhi-Bang Y. A case of ectopic fascioliasis in the skin. Trop Doct 2010; 40: 253-4. [CrossRef] 